\title{
FORMATION OF ETHNO-EDUCATION IN THE CONTEXT OF THE MODERN ETHNOCULTURAL SPACE
}

\author{
(C) Elena I. Zritneva, Nadezhda P. Klushina, Yuri A. Lobeiko
North-Caucasus Federal University, Stavropol, Russian Federation zritneva@mail.ru

The revival of the cultural potential of each people and its disclosure through the education system, the inclusion of social and pedagogical processes into the content of the education of ethnic culture are the most important tasks of modern society. The global challenge of civilizational development is the creation of a single multicultural and educational space based on a multilateral dialogue of cultures that promotes the mental compatibility of people in the context of their complementarity and mutual enrichment. Based on the ethnoculturological approach, the essential characteristics and basic structural components of the ethnocultural education system are determined, and personal, ethnopedagogic, linguistic, bilinguistic and moral aspects of the education system are revealed. From the point of view of procedural and efficient approach the essence of ethnocultural education system is interpreted as a process and a result of socio-historical development of ethnos, its main trends and features, and the readiness for ethnic self-identification is interpreted as a core quality in the structure of ethnic culture. It is alleged that the study of the ethnocultural environment in the system of formation and the pedagogical foundations of its formation should contribute to the realization of the cultural core of the content of education on the basis of universal human and regional values.

Key words: personality, culture, socialization, education, ethnocultural environment, ethnocultural education system, personality-oriented education, ethnocultural principles of morality.

\section{[Е.И. Зритнева, Н.П. Клушина, Ю.А. Лобейко Формирование этнопедагогики в контексте со- временного этнокультурного пространства]}

Возрождение культурного потенциала каждого народа и его раскрытие посредством системы образования, включение социально-педагогических процессов в содержание образования этнической культуры - важнейшие задачи современного общества. Глобальная задача цивилизационного развития: создание единого поликультурного и образовательного пространства на основе многостороннего диалога культур, способствующего ментальной совместимости людей в условиях их взаимодополнения и взаимообогащения. На основе этнокультурологического подхода определяются сущностные характеристики и основные структурные компоненты этнокультурной системы образования, раскрываются личностные, этнопедагогические, языковые, билингвистические, нравственные аспекты системы образования. С позиций процессуально-результативного подхода сущность этнокультурной системы образования трактуется как процесс и результат социально-исторического развития этноса, его основных тенденций и особенностей, а готовность к этнической самоидентификации - как стержневое качество в структуре этнической культуры. Утверждается, что исследование этнокультурной среды в системе формирования и педагогических основ ее формирования должны способствовать реализации культурного ядра содержания образования на основе общечеловеческих и региональных ценностей.

Ключевые слова: личность, культура, социализация, воспитание, этнокультурная среда, этнокультурная система образования, личностно-ориентированное образование, этнокультурные принципы нравственности.

Elena I. Zritneva - Ph.D. (Advanced Doctorate) in Pedagogy, Professor, North-Caucasus Federal University, Stavropol, Russian Federation.

Nadezhda P. Klushina - Ph.D. (Advanced Doctorate) in Pedagogy, Professor, North-Caucasus Federal University, Stavropol, Russian Federation.

Yuri A. Lobeiko - Ph.D. (Advanced Doctorate) in Pedagogy, Professor, North-Caucasus Federal University, Stavropol, Russian Federation.

Зритнева Елена Игоревна - доктор педагогических наук, професссор, Северо-Кавказский федеральный университет, г. Ставрополь, Российская Федерация. 
Клушина Надежда Павловна - доктор педагогических наук, профрессор, Северо-Кавказский фредеральный университет, е. Ставрополь, Российская Федерация.

Лобейко Юрий Александрович - доктор педагогических наук, профрессор, Северо-Кавказский фредеральный университет, е. Ставрополь, Российская Федерация.

In pedagogy the ethnic revival manifests itself as ethnopedagogy, an actively developing field of human education science. Within the framework of ethnopedagogy valuable experience of preservation and re-establishment of ethnocultural identity of modern sociality in society has been compiled [1, pp. 168-177], methodological provisions on which human education is based in the conditions of a multinational State have been formulated.

The idea of Y.A. Komensky about the nationality of education is enriched by K. D. Ushinsky, who argued that it is impossible to ignore the existence of each people's own system of education, on which the effectiveness of the pedagogical process depends. He neither singles out nationalities nor focuses on national ones. Only by rising to the top of the culture the person can reveal universal human values for himself and learn the world culture. "Culture is understood as the inner essence of human ideas..." [10, pp. 3-9]. The cultural and pedagogical heritage of each ethnic group contains a unique educational potential that can be successfully realized through the education system. The mainstreaming of traditional pedagogical views and achievements of ethnic culture should become the main factor in the formation of the moral, ethical and social base of the personality. It had been formed in various historical periods of society development [3, pp. 45-49].

The conditions for the formation of modern ethnoculture; the strategy of revival and support of cultures; the ethnocultural identification; the integrating function of the language, the ethnolinguicultural component of the content of education; bilingualism in education as the interaction of cultures, are fundamental to ethnopedagogy.

Ethnoculture is viewed in organic connection with the history of development of the people, its mentality, the stereotype of national character, and it is defined as a means of development and education of the basic ethnic personality, of the carrier of national identity.

Based on the ethnoculturological approach the essential characteristics and basic structural components of the ethnocultural education system are determined, and personal, ethnopedagogic, linguistic, bilinguistic and moral aspects of the education system are revealed. From the point of view of procedural and efficient approach the essence of ethnocultural education system is interpreted as a process and a result of socio-historical development of ethnos, its main trends and features, and the readiness for ethnic selfidentification is interpreted as a core quality in the structure of ethnic culture.

The study of the ethnocultural environment in the system of formation and the pedagogical foundations of its formation, the identification of principles should contribute to the realization of the cultural core of the content of education on the basis of universal human and regional values [4]. The realization of the cultural-creative function, which ensures preservation, transmission, reproduction and development of culture through education, involves, first of all, the education of the human being of culture, the selection of culturecongruent content and the re-establishment in the national educational system of cultural samples and norms designing visible elements of the cultural environment, the culturecongruent structure of children's life.

Education is considered as an essential structural element in the process of revival, preservation and development of ethnic culture. Multi-disciplinary and interdisciplinary reflect assimilation and integration of scientific data on education, of objective provisions of psychology, philosophy, history, cultural studies, anthropology vividly. This provides an aspectual and conceptual vision of the essence of education and ethnoculture, their dy- 
namic and dialectical nature. At the same time, it is quite convincing and reasoned to emphasize such eternal values and creative ideas and positions as a historical-material and spiritual traditional continuity of ethnocultural development, and a calendar tradition.

The concept of the developing ethnocultural education system and the scientific and pedagogical basis of the design and formation of a bilingual ethnocultural school, in the context of the personality-oriented educational paradigm, guide the personality towards universal human values through ethnic culture. Value orientations of ethnoculture ensure systemicity and integrity of the personality formation. The pedagogical condition for the formation of modern ethnoculture is a set of joint educational collective activities of students to learn social experience. The systemically important factor in the formation of modern culture is humanistically directed, socially significant joint activities of students (representatives of different ethnic groups).

The education system is considered to be the most important structural element of the process of revival, preservation and development of ethnic culture. The preservation of the values of ethnic culture and the acceptance of universal human values by the object of the educational process largely depends on the orientation of the educational system towards ethnic culture as an integrative social and personal phenomenon. "Culture is an essential characteristic of the social sphere of society, it is inseparable from the social activity of man" [5, pp. 74-78].

The national-regional education system acts as a kind of organizational structure, ensuring the inclusion of ethnocultural connotated educational systems into the multicultural educational space, the uniform level of quality and the accessibility of education, the agreed democratic inter-ethnic policy in the field of education. National-regional educational systems possess the highest relevance, self-significance and the state of being relevant in time, modern social, cultural and educational reality. This is a pedagogical, or, more precisely, ethnopedagogic instrument, perhaps even the main instrument of federalization, federal structure and existence of a multinational Russian State, which means a lot for the reasonable national policy regulating not only inter-ethnic but also interpersonal relations in the multi-ethnic environment, in the multicultural society.

The modern period is characterized as a period of formation of national-regional systems of education, which, in one way or another, form the national character. The national character can be learnt by studying the national system of education [2, 85 p.]. The principle of ethnocultural connotation, which emphasizes the ethnocultural feature of modern education is particularly important as a leading principle in the design of national-regional education systems. Education is considered as an essential structural element in the process of revival, preservation and development of ethnic culture. The problem of ethnocultural connotation of education is paramount in a series of multi-ethnocultural studies. The concept of ethnocultural connotation reveals and actualizes the ethnocultural feature of the modern educational system as a socio-historical phenomenon that focuses on the preservation and development of ethnic culture, as the formation of a person in the process of educational activity depends on the depth of learning of the cultural experience of the people. The principle of ethnocultural connotation of education is realized through the continuous process of transmission from generation to generation of spiritual values, ethnocultural traditions and features reflecting different aspects of life support, which are manifestations of ethnocultural memory. The entry of students into the ethnic culture environment is a factor of the formation of the moral, ethical and social base of the personality, which is characterized by "public consciousness... common cultural norms and values" [7, pp. 6-12], which is closely related to historical memory [11, pp. 41-47]. It is necessary to organize the system of upbringing and education based on scientific research of forms, methods, directions and mechanisms of personal development [8, pp. 15-18]. 
Ethnocultural connotated system of education is considered as a system that ensures preservation and development of ethnic constants of the central cultural theme of ethnos. It is optimized through ethnolinguulological themes present in all structural components of the system. This ensures the development in the student of confidence in his/her abilities, the formation of ethnic identity and ethno-planetary thinking, the responsibility for preservation and development of cultural tradition, including religious tradition [6, 155 p.]. It also notes the influence of Orthodoxy on the formation of Russian culture [9, 60 p.].

The ethnocultural component of education is inextricably linked to the language performing the integrating function. The pedagogical justification of the cultural function of the native language, its writing, those norms of behavior which are encoded in the meanings of words, phraseologisms, in the works of the folk epic is relevant. Taking into account the achievements of linguoculturology, the huge layer of special research in the field of ethnography, ethnology, sociolinguistics, cultural studies, philosophy is being considered. On the basis of an in-depth analysis, the essence of ethnolinguicultural determination of modern education and the role of the mother tongue as a carrier of ethnocultural specificity in the content of modern education is scientifically justified.

Socialization of younger members of society in the context of natural bilingualism will be more effective if teachers take maximum account of the cultural potential of their mother tongue, combined with the capabilities of Russian as a means of intercultural communication. This is important for those ethnic groups that, for various reasons, have been put on the verge of losing their identity.

In order to form the parity National-Russian bilingualism with priority usage of the native language as a means of studying, it is necessary to create prerequisite for the development of equality of languages and cultures. It is important to expand the scope of communication in the mother tongue through teaching in the mother tongue. The ethnic component in education is inextricably linked to the language, it is oriented towards the development of the student as a person, rising from the native ethnic culture to the world through the all-Russian culture. The question of the language of instruction in the context of revival of the mother tongue is acute. It is necessary to expand the sphere of communication in the native language, which is possible if the language becomes the language of instruction. The parallel existence and mutual enrichment of languages is an essential tool for preservation of ethnic minorities in the modern multi-ethnic world.

Mechanisms of revival and development of ethnoculture in the education system are very important. Personal-oriented education and personal approach are the methodological principle of design of ethnocultural education system.

One way to move towards genuine humanistic education systems at the State and regional levels is the establishment of such educational systems which would promote the full disclosure of the personality, the revival and development of numerous Russian ethnicities. The ethnocultural component is an essential quality of the personality and it has a great humanistic potential for its development and formation. The deliberate and systematic usage of progressive achievements of elements of ethnic culture is a serious prerequisite for the formation of intelligence and the improvement of the personal structure of the young generation. As it is known, the focus of the personality is expressed in needs, interests, beliefs and motives of behavior. It is also important to study the abilities, gifts, will and morality of the personality.

The principle of ethno-cultural connotation is put forward as the methodological basis of design, the essence of which is the provisions on mainstreaming of ethnogenetic, linguistic and social mechanisms of learning of ethno-cultural experience, which manifests itself in dialectical unity of the three beginnings: ethnic, inter-ethnic and world. The principle of ethnocultural connotation of the education system and the scientific and pedagogical basis of the design and formation of a bilingual ethnocultural school contribute to the de- 
velopment and design of modern educational models. But it is very difficult to determine the specifics of the design and management of ethnocultural connotated education, to determine the ethnocultural component organically embedded into this education system and to identify the psycho-pedagogical conditions of its learning by students.

On the basis of the principle of ethnocultural connotation, the project of the educational system is being created, which includes the objectives of the educational process, the level content of ethnocultural experience in the system of subjects of national-regional competence, pedagogical technologies and the model of management of educational institutions at various levels.

The basis of this model of the education system is the usage in the educational process of universal human and ethnocultural principles of morality, which will fill the increasing deficit of ethnocultural interaction in modern multi-ethnic society, the usage of the level content of ethnocultural experience in the system of subjects of national-regional competence corresponding to education goals.

The positive and personal articulation of the content of education is relevant and practically significant not only for the modern national-regional education system, but also for all pedagogical science. Its humanistic character implies, first of all, a multidimensional intellectual, ethnocultural, psychological, social and multicultural level of personal development. Here there are principles not only of ethnopedagogic dialogue of cultures, but also of creative expediency of consumption, preservation and creation of new cultural values.

Since the 1990s, the process of diversification of education and development of national-regional education systems began. Repeated attempts to reform them did not change the conceptual basis that's why they had not led to major successes. In the Law of the Russian Federation "On Education" one of the most important principles is the principle of protection of the system of education of national cultures and traditions in the conditions of a multinational State. The rejection of the unitary model of education has contributed to the emergence of multilingualism, multidisciplinary nature of various types of educational institutions, the expansion of the range of multi-level educational programs, the consideration of ethno-regional characteristics of culture, the formation of national-regional education systems. The education system is faced with the tasks of restoring the cultural potential of each ethnic group and preserving it through the education system, focusing the content of education on the preservation and development of ethnic traditions in the educational activities of educational institutions.

The modern education system of the Russian Federation is in the process of modernization. The draft National Doctrine of Education of the Russian Federation states that as a priority task the education system is intended to ensure the historical continuity of generations, preservation, dissemination and development of national culture; education of patriots of Russia, of citizens of the democratic and social State, respecting the rights and freedoms of the personality and having moral rectitude. At the beginning of the 21 st century domestic education reached the level of formation of ethnocultural personal-oriented education systems.

The important place in ethnocultural education is taken by media education and its means: press, television, radio, cinema, broadband Internet paying much attention to familiarizing of people with cultural wealth. This makes it possible to avoid closure, to reach the level of comparison, to compare different approaches to pedagogy in different countries. 


\section{Лumepamypa}

1. Бакланова О. А., Бакланов И. С. Современная российская социальность в контексте социального конструкционизма // Вопросы социальной теории. 2015. Т. 7. № 1-2. C. 168-177.

2. Вигель Н.Л. Человек и вызовы глобализации // Сервис plus. 2016. Т. 10. № 4. C. 84-88.

3. Гончаров В. Н. Социальный аспект религии в контексте развития первобытного общества // Гуманитарные и социально-экономические науки. 2016. №2 (87). C. 45-49.

4. Дашкова Е.В., Ивушкина Е.Б. Музееведение / учебное пособие для вузов. Шахты: ЮРГУЭС, 2009.

5. Ерохин А. М. Социально-философрские аспекты развития культурной сферы общества // Экономические и гуманитарные исследования регионов. 2016. № 1. C. 74-78.

6. Карташев А.В., Склярова Е.К., Камалова О.Н. Олимпиады по истории медицины: опыт организации и особенности проведения // Гуманитарные и социальноэкономические науки. 2017. № 1 (92). С. 151-156.

7. Колосова О. Ю. Духовная сфера: универсализм и самобытность // European Social Science Journal. 2012. №11-2(27). C. 6-12.

8. Лобейко Ю. А. Социально-педагогический аспект активности личности в системе общественного развития // Экономические и гуманитарные исследования регионов. 2015. №1. С. 15-18.

9. Матяш Т.П., Несмеянов Е.Е. Проект модернизации - европейский соблазн / /Вестник Волгоградского государственного университета. Серия 7: Философия. Социология и социальные технологии. 2011. № 2 (14). С. 57-61.

10. Berkovskiy V., Tronina L. Social and historical aspect of interaction of ethnic culture and personality in the context of public development // Научный альманах стран Причерноморья. 2019. №1(17). С. 3-9.

11. Kuleshin M., Leonova N., Nemashkalov P. Historical consciousness as a part of national consciousness: to the problem statement of the research // Научный альманах стран Причерноморья. 2019. №1(17). С. 41-47.

12. Shestakov Yu.A., Nesmeyanov E.E. L.P. Karsavin's historiosophy in the light of basic problems of russian national security protection // Научный альманах стран Причерноморья. 2015. № 4 (4). С. 16-20.

\section{References}

1. Baklanova O. A., Baklanov I. S. Sovremennaia rossiiskaia sotsialnost v kontekste sotsialnogo konstruktsionizma. Voprosy sotsialnoi teorii. [Modern Russian sociality in the context of social constructionism. Issues of social theory.]. 2015. V. 7. No. 1-2. pp 168-177 (in Russian).

2. Vigel N.L. Chelovek i vyzovy globalizatsii. Servis plus. [The man and the challenges of globalization. Service plus.]. 2016. V. 10. No. 4. pp. 84-88 (in Russian).

3. Goncharov V. N. Sotsialnyi aspekt religii v kontekste razvitiia pervobytnogo obshchestva. Gumanitarnye i sotsialno-ekonomicheskie nauki. [Social aspect of religion in the context of development of primitive society. Humanitarian and socio-economic sciences.]. 2016. No. 2 (87). pp. $45-49$ (in Russian).

4. Dashkova E.V., Ivushkina E.B. Muzeevedenie. Uchebnoe posobie dlia vuzov. Shakhty: IURGUES. [Museology. Teaching manual for universities. Shakhty: South Russian State University of Economics and Service]. 2009 (in Russian). 
5. Erokhin A. M. Sotsialno-filosofskie aspekty razvitiia kulturnoi sfery obshchestva. Ekonomicheskie i gumanitarnye issledovaniia regionov. [Socio-philosophical aspects of development of the cultural sphere of society. Economic and humanitarian studies of the regions.]. 2016. No. 1. pp. 74-78 (in Russian).

6. Kartashev A.V., Sklyarova E.K., Kamalova O.N. Olimpiady po istorii meditsiny: opyt organizatsii i osobennosti provedeniia. Gumanitarnye i sotsialno-ekonomicheskie nauki. [Academic competition on the history of medicine: experience of organization and peculiarities of carrying out. Humanitarian and socio-economic sciences.]. 2017. No. 1 (92). pp. 151-156 (in Russian).

7. Kolosova O. Yu. Dukhovnaia sfera: universalizm i samobytnost. European Social Science Journal. [Spiritual Sphere: Universalism and Identity. European Social Science Journal]. 2012. No. 11-2(27). pp. 6-12 (in Russian).

8. Lobeiko Yu. A. Sotsialno-pedagogicheskii aspekt aktivnosti lichnosti v sisteme obshchestvennogo razvitiia. Ekonomicheskie i gumanitarnye issledovaniia regionov. [Social and pedagogical aspect of individual activity in the social development system. Economic and humanitarian studies of the regions.]. 2015. No. 1. pp. 15-18 (in Russian).

9. Matyash T.P., Nesmeyanov E.E. Proekt modernizatsii - evropeiskii soblazn. Vestnik Volgogradskogo gosudarstvennogo universiteta. Seriia 7: Filosofiia. Sotsiologiia i sotsialnye tekhnologii. [Modernization project - European temptation. Journal of the Volgograd State University. Series 7: Philosophy. Sociology and Social Technology]. 2011. No. 2 (14). pp. 57-61 (in Russian).

10. Berkovsky V., Tronina L. Social and historical aspect of interaction of ethnic culture and personality in the context of public development. Science almanac of Black Sea Region Countries. 2019. No. 1(17). pp. 3-9.

11. Kuleshin M., Leonova N., Nemashkalov P. Historical consultation as a part of national consultation: to the problem statement of the research. Science almanac of Black Sea Region Countries. 2019. No. 1(17). pp. 41-47.

12. Shestakov Yu.A., Nesmeyanov E.E. L.P. Karsavin's historiosophy in the light of basic problems of Russian national security. Science almanac of Black Sea Region Countries. 2015. No. 4 (4). pp. 16-20. 